\title{
Immigrant political socialization as bridging and boundary work: mapping the multi-layered incorporation of Latin American immigrants in Toronto
}

\author{
Patricia Landolt and Luin Goldring
}

\begin{abstract}
We present a longitudinal map of three overlapping organizational trajectories developed by Latin American immigrants in the city of Toronto. We propose the concept of bridging and boundary work to specify how new (1) intersectional political identities and organizational agendas are constituted by Latin American feminist women and artists in the interstice of (2) country-of-origin and (3) mainstream pan-ethnic organizations. Boundary work occurs as activists with intersectional priorities carve out a distinct political agenda; the 'out-group' relations based on a shared sectoral focus constitute bridging work. Tracing changes in the local and transnational political opportunity structures, we consider how negotiations over resources, representation and agendas between these three Latin American organizational forms generate multidirectional political learning and socialization and the coexistence of different Latin American political cultures. We define political socialization as in-group and out-group encounters between political cultures understood as civic toolkits or ways of doing politics.
\end{abstract}

Keywords: Immigrant political incorporation; political socialization; bridging and boundary work; community organizations; Latin Americans; Canada.

Recent efforts to understand the complexity of immigrant politics rest on a redefinition of political incorporation understood as a contextcontingent social process in which political socialization occurs via the institutionally mediated encounter between political cultures (Gerstle and Mollenkopf 2001; Jones-Correa 2001; Rogers 2006). There is a resurgent interest in immigrant grassroots organizing and associational life as a mezzo-level ${ }^{1}$ entry point for understanding pathways of 


\section{Patricia Landolt and Luin Goldring}

political incorporation (cf. Jones-Correa 2002). Institutional studies of immigrant community politics capture the importance of contexts, resources and political opportunity structures for explaining the links and disconnects between immigrant civic engagement, grassroots mobilization and electoral participation and representation (e.g. Hardy-Fanta 1993; Cordero-Guzman 2005). They also use variation in contextual factors and group resources to construct typologies of organizational forms (e.g. Portes, Escobar and Radford 2007). However, a limitation of institutional research is that it tends to focus on the cross-sectional study of clearly detectable, discrete organizations (Moya 2005), and assumes that ethno-national identity is the central platform and container for immigrant associational life (GlickSchiller, Cağlar and Guldbransen 2006). These synchronic studies obscure more sporadic organizational forms, make mobilization in which ethno-nationality is not primary invisible and cannot explain the development of pathways of political incorporation over time. They fail to capture how political identities and organizational agendas develop, the decline of organizations, overlaps and relationships between organizations, both within the immigrant group and beyond, and the extent to which a group's organizational landscape as a whole is dynamically multi-layered.

We trace the rise and consolidation of political identities and organizational agendas developed by Latin American women and artist activists in the city of Toronto; ${ }^{2}$ forms of organizing that deemphasize the ethnic dimensions of identity and emerge in the interstice of Latin American country of origin and mainstream panethnic groups. The constitution of an intersectional Latin American politics involves a dual movement: first, women and artists challenge the ways in which nationality based and mainstream pan-ethnic organizations do politics; second, they identify alternative allies both within the Latin American community and outside it. In this way intersectional pan-ethnic groups redefine their relationship with established Latin American organizations and expand the range of practices associated with the Latin American process of political incorporation in Toronto. They open new possibilities for crosssectoral dialogue and alliance-building, produce policy shifts and some institutional mainstreaming.

Taking up Vertovec's (2007) challenge, we develop a longitudinal analysis of political incorporation for a numerically small, heterogeneous population in an immigrant gateway city characterized by super-diversity. We chart the relations of competition and collaboration sustained between Latin American country-of-origin, mainstream pan-ethnic and intersectional pan-ethnic organizations. Negotiations over resources, representation and agendas generate political learning, organizational layering and the coexistence of varied Latin American 
political cultures. We offer the concept of bridging and boundary work (cf. Brettell 2005) to specify how political socialization, understood as the acquisition and/or modification of political repertories and orientations occurs. In-group collaboration and contention constitute boundary work as activists with intersectional priorities carve out a political identity and agenda distinct from that of country-of-origin and mainstream pan-ethnic Latin American groups; 'out-group' relations based on a shared sectoral focus constitute a form of bridging work. Intersectional organizing generates in-group critiques that test and stretch established ways of doing politics, and lay the bases for developing alliances with other ('out') groups, producing the potential for multi-directional and multi-polar change in political cultures.

We proceed as follows. We advance a conceptual framework for the mezzo-level, institutional analysis of political incorporation. Then we discuss Latin American migration to Canada and the trajectories of country-of-origin and mainstream pan-ethnic Latin American groups in Toronto. This is followed by the two case studies and a concluding discussion.

\section{Political incorporation as a multi-layered social process}

The focus on immigrant political incorporation as a context-contingent social process of socialization reflects a multi-pronged critique of established scholarship on immigrant politics. Political behaviour studies that explain rates of electoral participation and modes of civic engagement based on variation in individual resources, such as time, civic skills and social capital (e.g. Verba, Scholzman and Brady 1995) have failed to yield consistent results for any group other than the white middle class (Garcia Bedolla 2005). They also offer a narrow definition of the kinds of civic engagement and political practice that lead to electoral participation and assume formal politics to be the normative end-goal for all groups (Theiss-Morse and Hibbing 2005). Neo-pluralist and minority group accounts struggle to explain the growing disconnect between grassroots civic engagement and electoral politics. Immigrant groups demonstrate dynamic community-based organizing and yet often remain disengaged from formal politics and off the radar of political parties (e.g. Siemiatycki and Isin 1997; Odmalm 2005; Wong 2006). Experiences of negative racialization, while linked to protest politics, have not generated the electoral coalitions predicted by the minority group model (Rogers 2006). Indeed, it is no longer so clear that immigrants gauge their political integration simply in relation to electoral participation in the host society (e.g. Escobar 2004). 


\section{Patricia Landolt and Luin Goldring}

Institutional scholarship draws on concepts such as political culture and political socialization to embed the study of immigrant politics in a sociological focus on social relations, organizations and trajectories or pathways of political incorporation. We test the limits of this conceptual framework, particularly as it is applied to the mezzo-level study of immigrant organizations. To begin, immigrant political socialization is understood as an encounter between immigrant and host-society political culture or ways of doing politics (Gerstle and Mollenkopf 2001). The term political culture however is often conflated with national culture understood as a set of shared cultural traits. As a result, national groups are associated with specific organizational forms assumed to be broadly representative of the way 'this nationality' does politics (Levitt 2005). An example of this pattern is the equation of Mexican migrants with hometown associations (HTAs). In Canada, however, Mexicans do not organize into HTAs and tend instead to create professional associations. Clearly, it is not national political culture but rather factors such as migration networks, social capital, class, etc., that determines organizational patterns.

We define political culture as a skill set or toolkit that is based on networks and shared political socialization and reflected in a group's mode of doing politics and established basis for organizing. Groups apply this toolkit in a flexible fashion to different situations or encounters (cf. Swidler 1986). In this light, the range and modes of immigrant politics are determined in part by the character and convertibility of pre-migration political skill sets. Posed as an encounter between skill sets, political socialization can be specified as a relational and potentially bi-directional process that transforms the civic toolkit of migrants and non-migrants alike (cf. Morawska 2001). The encounters that organize immigrant politics transform local ways of politics and can thus become an enduring feature of the political opportunity structure (cf. Pero 2007).

The concept of political opportunity structure is well developed in the literature. The political opportunity structure [POS] sets the normative and instrumental parameters of membership and participation in the political system (Bloemraad 2006). The politics of ethnicization intersect with other POS elements such as the organization of government bureaucracies. This occurs when the capacity to make demands on state and non-state institutions rests on a group's ability to constitute itself into a recognizable ethnic collective (Bannerji 2000). Understanding how groups become ethnic collectives as they constitute political identities and organizational agendas also sheds light on how they read the signals of a political opportunity structure. Our focus complements but diverges slightly from work on panethnicity, which argues that inter-ethnic coalition building develops for 
instrumental or strategic reasons (Espiritu 1992; Trinh Võ 2001). While this literature sees pan-ethnicization as a strategic response, it does not capture how the constitution of new pan-ethnic political identities and organizational agendas occurs and changes over time. Intersectional pan-ethnic politics suggest that over time ethnicity may be displaced as a feature of collective identity and mobilization.

In the Canadian case, immigration trends and multiculturalism policy combine to make ethnicity an organizing principle of institutional relations. While the funding directives of multiculturalism policy have changed since its formal launch in 1971, the policy demands ethnic distinctiveness for group recognition (Breton 1984). At the same time, the tremendous diversity of immigration source countries, together with the geographic dispersal of immigrant populations both across the country and within cities, encourages 'community' organizing according to broadly defined and implicitly racialized panethnic blocks based on language (e.g. Hispanic, Francophone) or region (e.g. Latin American, South Asian). In turn, the ethnicizing politics of multiculturalism play into the design and delivery of statefunded settlement and social services (Bannerji 2000). Programmes are delivered through community agencies that are typically organized following state-generated pan-ethnic, ethno-national or ethno-religious categories (Richmond and Shields 2005). Community organizations, particularly those funded to deliver social services are thus effectively charged with articulating the priorities and agenda of 'the ethnic collective'. As we examine for the Latin American case, the ethnicizing imperative of the state frames out-group and in-group negotiations around political identities and organizational agendas.

Finally, the concept of pathways of political incorporation, although not fully developed, helps bridge the often-drawn distinction between civic engagement - understood as participation in voluntary, non-governmental associations - and political participation, defined more narrowly as electoral politics. It challenges the assumption of a linear relationship between civic engagement and formal political participation and moves us towards a process-oriented approach to immigrant politics (Theiss-Morse and Hibbing 2005). We use pathways of political incorporation to refer to ongoing and mutually constitutive processes associated with political socialization that contribute to the possibility of immigrants participating in activities and institutions of their destination country that affect the terms of their existence (Magnusson 1990).

Focusing on immigrant organizations, we develop a longitudinal analysis of the constitution of new political identities and organizational agendas that challenges the bias towards the cross-sectional study of clearly detectable organizations. We examine intersectional pan-ethnic organizations that emerge in the interstice of Latin 
American nationality-based and mainstream pan-ethnic organizing. We propose the concept of bridging and boundary work, understood as in-group and 'out-group' encounters between civic toolkits, to explain how new political identities and organizational agendas are developed. Tracking the formation of new political voices and organizational trajectories helps explain: how political socialization occurs through the encounter of civic toolkits; how political opportunity structures are transformed by immigrant politics; how new layers or trajectories of political action are added to a pathway of political incorporation; and how the relevance of ethnicity as an organizing principle shifts across these different layers.

\section{Mapping organizational trajectories}

In our research we examined the organizational trajectories of Latin American immigrants in Toronto for a thirty-year period starting in the 1970s. Our focus on institutions, as opposed to individuals, is based on the idea that community organizations reflect collective projects, social locations and claims around membership in political and other types of community. In spite of the contentious relationship between individuals and 'representative' institutions, organizations offer a window into political action.

Data for the paper come from thematically organized focus-group interviews conducted in 2004 and 2005 (N 18; approx. 100 participants) and individual follow-up interviews conducted in 2007-8. We also use interviews from an earlier project 'Civic Engagement of Latin Americans in Toronto' [CELAT] carried out by the second author. We began by bringing together people based on their experience in national origin, women's and pan-ethnic social service organizations, for a total of seven group interviews: 1) Salvadorans, 2) Guatemalans; 3) Colombians; 4) Chileans; 5) women; 6) umbrella organizations; and 7) Canadian international solidarity groups (including unions, churches and academia among others). This first set of interviews revealed the importance of other themes and forms of organizing. We conducted additional interviews with: 1) indigenous rights organizations; 2) church groups; 3) priests; 4) educational groups; 5) art and performance groups; and 6) experts in the area of mental health and immigration, as well as an interview with 7) Canadians and Latin Americans working in the area of refugee rights and advocacy.

Each focus group brought together previously or currently active community leaders. We asked participants for basic socio-demographic information, but the emphasis was on their participation in the collective life of their communities and organizations. Group discussion mapped organizations in order to locate them in time and in relation to one another. We asked groups to identify features of each 
organization they named, including: when it was founded (when, why, by whom); organizational structure, membership criteria and size (and how these changed); agendas/objectives (in Canada, in country of origin, elsewhere); key allies among other immigrant and nonimmigrant organizations in Canadian and beyond (including settlement agencies, government bureaucracies, elected officials, unions, advocacy groups, etc.); longevity and reasons for folding if no longer in existence; funding sources and strategies; challenges; internal cleavages and so on. A summary report of sessions was circulated to participants for feedback, after which reports were revised.

\section{Laying the groundwork: country-of-origin and mainstream pan-ethnic organizations}

The Latin American population of Canada is quite heterogeneous in terms of its modes of entry, immigration status upon entry and countries of origin. Mata (1985) characterized Latin American migration to Canada as occurring in four waves, based on changes in Canadian immigration policy and events taking place in countries of origin. The first was the 'lead wave' of European-origin stepmigrants that arrived through the early 1960s; second, in the late 1960s and early '70s, was the 'Andean wave' of Ecuadorian, Colombian and Peruvian economic migrants; third, the 'coup wave' of political refugees from Chile, Argentina and Uruguay, which started in 1973 and continued through the 1970s; and, fourth, the 'Central American' wave that fled civil wars during the 1980s. The 1990s was characterized by a further diversification of modes of entry and demographic profiles. Latin American migration now includes a growing number of unauthorized migrant workers from Costa Rica, Brazil, Mexico and Argentina, an expansion in temporary migrant worker programmes and a new stream of professionals from Mexico, Colombia and Argentina (Goldring 2006).

Over the years, Latin Americans in Toronto have created a variety of organizations including: 1) nationality-based cultural groups, sports clubs and transnational political organizations among others; 2) social service and advocacy-related mainstream pan-ethnic organizations; and 3) inter-sectional pan-ethnic organizations that address issues related to experiences of racialization, class, sexuality, gender, etc. Latin Americans have also participated in sectorally focused collectives, such as unions and immigrant rights organizations. For each layer in this organizational landscape, political priorities and organizational agendas have expanded or dwindled over time and in relation to contextual changes. Change is generated through: the arrival of new Latin American migrant populations; dialogue across and political learning 
by differently organized Latin American groups; the accumulation of institutional capacities; and shifts in the political opportunity structure.

For each migration wave, nationality has been an important starting point for civic engagement. Conditions of exit from countries of origin, especially the degree to which departure is forced or voluntary, the duration and types of political violence and the Canadian context of reception have shaped the modes and basis of organizing developed by each population (Landolt and Goldring 2006). Migrants leaving welldefined political conflicts, who entered Canada as refugees, maintained fairly stable political bases of organization. Examples include refugees from Chile and El Salvador. Pre-migration socialization within leftist political parties, guerrilla movements and grassroots social movements are reflected in both groups' modes of organizing. Both Chileans and Salvadorans created transnational partisan organizations that carried out fundraising for political prisoners and the underground opposition in home countries, conducted outreach and education with Canadians around human rights violations and denounced Canadian corporate investment in Latin America.

In contrast, migrants leaving contexts where political violence was protracted and produced widespread fear have either had difficulties developing stable community organizations or have organized in ways that avoid home country politics. The former pattern is seen among Guatemalans (Nolin 2006) and the latter among Colombians (RiañoAlcalá and Goldring 2006). Thus, the Toronto-Guatemala Solidarity Committee developed a transnational partisan agenda but struggled to gain the trust of Guatemalan refugees. The Colombian agenda is quite dispersed and apolitical. It includes ethno-national celebrations, charity work and business and professional associations. Colombian transnational politics exist but are detached from nationality-based organizing. Where civil conflict is not as clearly articulated, ethnonational identity remains an important point of reference. Ecuadorians and Peruvians, for instance, have created nationality-based sports and cultural groups (Romero 1985).

Mainstream pan-ethnic institutions, most notably the Centre for Spanish Speaking People [CSSP] and the Hispanic Development Council [HDC], emerged in the 1970s to meet the early settlement needs of South American refugees. The CSSP was created by Spanish women with financing from the Communist Party of Spain to offer childcare and services for refugee women from Chile. The founding group's own leftist politics informed their identification with Latin American refugees and their solidarity was expressed through their responsive and creative approach to service provision. The centre's early success produced a period of growth and institutionalization, the development of multiple and varied partnerships and diversification of funding sources. Founded in 1978, the HDC took on a different role as 
the lobbying, research and analysis arm of the community. Its research and dissemination capacities and its claims to legitimacy within the Latin American community have made it an attractive interlocutor for out-group stakeholders.

In the 1990s, the implementation of new public management theory restructured relations between the state and the voluntary sector. Social service agency funding was reduced and restructured away from core funding towards targeted and time-delimited contracts and there was pressure to separate advocacy from service delivery (Richmond and Shields 2005). In this context, the CSSP mainstreamed services to ensure continued funding; community members become clients of services and a long-standing tradition of horizontal consultation weakened. The HDC became increasingly instrumental, often redefining priority agendas in line with external calls for funding. Sectorally based collaboration and dialogues among differently organized Latin American groups dwindled and competition ensued.

\section{Formed in the interstice: intersectional Latin American politics ${ }^{3}$}

The articulation of an intersectional Latin American politics involves negotiations, collaboration and competition among various in-group and out-group stakeholders. Our longitudinal analysis poses immigrant political socialization as encounters across civic toolkits or ways of doing politics. These encounters involve a dual movement: Latin American women and artist activists engage in boundary work as they develop a critique of the ways of doing politics of Latin American nationality-based and mainstream pan-ethnic organizations; they do bridging work as they establish relations with out-group interlocutors based on a shared intersectional or thematic focus.

\section{Artists: from transnational partisan politics to opening spaces for cultural work}

Individuals in the arts focus group shared a critical stance towards the arts: they rejected the commercialization of Latin American cultures and identities, saw the arts as a form of consciousness-raising and were concerned about how artistic work should be produced, for whom and with what purpose. The data suggest two phases in the constitution of a political identity and agenda by Toronto's progressive Latin American artists.

In the 1970s, Latin American artists functioned as political volunteers for country-of-origin organizations. In particular, artists affiliated with transnational partisan organizations had a two-fold mandate: the preservation and celebration of national cultures and fundraising in accordance with the strategic priorities of their 
organization. As a Chilean musician recounted, artists were strongly committed to this role:

At the beginning the artists make their contribution voluntarily. We wanted to show that we were not as defeated as they thought. It didn't matter if they paid you or not.... In the peñas and ... busking on the street ... we denounced the international corporations ... all those things. ... We began to realize that through the partisan political organizations we were not accessible but culture could be a medium through which we could engage others. Chilean organizations were extremely militant and this closed off any possibility for people to get close to us. The other objective was also to carry out, apart from consciousness-raising, fundraising to support in some way the struggles that existed in our countries. (Arts, 2)

Artistic production facilitated cross-cultural dialogue and political education in the name of a transnational partisan agenda.

During this period, the Latin American artists formed a wellfunded, productive and progressive cross-cultural network. Artists created institutional spaces that encouraged dialogue, even across the ideological differences of transnational politics. 'We circulated in the peñas related to the Chilean resistance ... afterwards in solidarity with El Salvador, with Nicaragua, and after it started to get wider ... from the Latin Americans we started to internationalize ... there was a lot of communication' (Arts, 7). The Trojan Horse - a small coffee house in Toronto's Greek neighbourhood - is emblematic of the period. Originally owned by two Greek brothers, it was sold to a Chilean organization and then sold to a Salvadoran group in the 1980s. Featuring well-known musicians, it became a popular place for progressive artists of different nationalities to meet and dream up new collaborations. A government-funded Latin American artists' collective was also formed and Chilean artist-militants created the record label Rebellion Records, which recorded well-known musicians of the Latin American new song movement, including El Salvador's Yolocamba Itá and the Nicaraguan Luis Enrique Mejía Godoy. A number of cultural-political magazines were also founded including $E l$ Libertario, La Pupusa and Venceremos.

Tensions eventually developed in the relationship between transnational political organizations and cultural workers as the vertical decision-making structures of the former clashed with the free-floating networks constituted by the artist community. Artists who challenged party orders were disciplined and banned from party-controlled spaces. Ideological differences among partisan organizations resulted in boycotts, gossip mongering and sabotage of competing cultural 
events. Musicians got tired of the restrictions imposed on their work: the pamphleteering tone preferred by partisan organizations; their emphasis on presenting 'national cultural traditions' for consumption at multicultural festivals; and their lack of interest in hybrid art forms. For many Latin American artists the experience of producing art in ethnically and politically mixed company, in contrast with the restrictions imposed by partisan organizations, confirmed their need for political and organizational autonomy.

In the 1990s, changes in the political opportunity structure altered artists' relations with Latin American and Canadian institutions. Negotiated transitions to democracy in South America and peace accords in Central America led to a decline in transnational partisan and international solidarity activities. New migration waves, particularly from Colombia, brought with them artists with limited knowledge of the partisan political projects of the past. At the same time federal and provincial cut-backs meant that artists' collectives, open art-spaces, alternative galleries and book rooms struggled to stay afloat. Artists sought out other funding sources and new ways to locate their work. As recounted by a curator and solidarity worker, the Buried Villages project of the Royal Ontario Museum is emblematic of this transition:

When the ROM put on The Living Maya Exhibit, they invited us. ... We decided to do a memorial of the 440 villages that were destroyed [during the civil war in Guatemala].... The Gardiner [Ceramic's Museum] supplied the clay, materials and the audience. We had people who came back again and again to make sure their village was there. The Guatemalans came ... on Sunday, from the different parties, and the Chileans and others, from the different parties. And they started adding names of people, of relatives ... on tiles. ... It became an incredible educational experience for these people who were just going to the museum. (Sol2, 1)

The entrance of Latin American artists into a Canadian social space thus facilitated the layering of transnational political histories and the establishment of Latin American cultural work as part of the local Toronto landscape.

In the late 1990s, Latin American artists struggled to conquer Canadian spaces of cultural work and to secure funding without falling into stereotypical notions of Latin American culture. As a young actor in the focus group exclaimed, 'There is a political struggle that is called opening spaces' (Arts, 6). An established dancer and choreographer added: 'There is critical art that asks why, for whom, and when. And based on this the doors open' (Arts, 1). Focus group 
participants recounted the kinds of obstacles they face in the film industry:

You can't fight against your accent. ... I was trying to break into an industry that has no roles for people with accents...and I ended up in Alucine 4 where I started to understand the political question differently, in terms of how the arts work in Canada and in terms of who controls the spaces and who has voice. (Arts, 6)

Artists have also found it difficult to produce art that is considered relevant by Canadians:

The galleries have an interest in Latin American art but what they want is stereotypes ... in the more vanguard or progressive galleries people want to see themselves reflected: but why should Canadians necessarily see themselves reflected in the art of a Latin American? (Arts, 3)

Latin American artists also recognized that participation in Canadian decision-making structures is important. But the arts-funding system created by multiculturalism policy was considered an obstacle to finding room: 'Multiculturalism ... makes things worse. If the $\mathrm{Na}$ tional Film Board sets aside 5 per cent of the budget for ethnics and so they bring in one Latin American and one Jamaican and with that they've filled the quota and we fight amongst ourselves' (Arts, 4). In 2003 Latin American artists created Aconsejate (council yourself), which held consultations between artists and the Canada Arts Council. However, this produced only minor changes specifically related to immigration status and funding eligibility criteria.

The constitution of an intersectional pan-ethnic politics by Latin American artists can be read as part of the process of immigrant political socialization. In the early settlement period, artists committed to transnational partisan organizations functioned like political volunteers. Through this partisan partnership, artists created both impromptu and formalized organizational spaces of artists-led collaboration (collectives, musical groups, coffee houses, peñas, etc.). In these spaces it was cultural work aligned with a commitment to radical social change, not ethnicity or pan-ethnicity, that was central to political identity. However, these experiences strained artists' commitment to country-of-origin-based transnational projects in part because of the restrictions these imposed on what they could perform and with whom they could work. In-group boundary work ensued as artists began to question nationality-base organizations' ways of doing politics and specifically partisan groups' impact on their identity as artists. Changes in local politics including funding cuts, regime change 
in countries of origin and the arrival of new migrants from other countries of Latin America tipped the balance to break this partnership. Bridging work occurred as Latin American artists entered into dialogue with each other, mending the ideological divides and bridging different migration experiences, and with the Canadian arts establishment, the funding agencies and the city's alternative arts spaces. Rooted in a civic toolkit that emphasizes social justice, for Toronto's Latin American artists 'doing politics' now means opening up existing and creating new spaces for the production of a critical Latin American art.

\section{From Latin American feminist politics to women's groups and programmes}

Focus-group participants traced the history of Latin American feminist and women's organizational activities in Toronto to the mid-1970s and named a great many women's groups, catalytic events, community organizations and women's programmes in social service agencies that grew out of this work. Two overlapping threads have defined Latin American women's activism: 1) the creation and maintenance of feminist spaces of political dialogue; and 2) the development of ethno-specific programming for women and children.

The earliest phase of Latin American women's organizing emerges from a critique of the ways of doing politics associated with transnational partisan organizations. During the late 1970s and early '80s, exile, refugee and immigrant women became aware of sharing contradictions between their lived experiences of domestic and political violence and the progressive rhetoric of the home-country organizations in which they participated. One feminist activist spoke eloquently about how these contradictions played out for her.

I was living parallel lives in terms of my politics and personal life; because the personal is political but I didn't really understand that at the time. ... [W]hen my compañero was violent with me it took me a long time before I dared to pronounce a word about this because he was my compañero, my comrade in the party, in the revolution; and so how was I going to dare to say that in our home relations were not so democratic nor egalitarian and that they were totally oppressive and that they resulted in violence. In other words, the same thing that we were denouncing in society, in Chile and in Canada ... that same thing was happening in my home. But still I didn't make that connection. But when I did ... I had the central committee of the ... party at my house questioning me. Questioning how I dared to criticize my comrade who was suffering from the effects caused by exile ... like exile wasn't affecting me. (CELAT 9) 
Discussions among women about these contradictions led to the establishment of the Latin American Women's Collective [LAWC, 1983-91], the first explicitly feminist Latin American organization in Toronto.

The LAWC developed a multi-layered feminist critique of maledominated country-of origin organizations. It offered an alternative space where feminism could be discussed, put into practice and contested; tensions around race and racism in the Latin American community and within the collective, the relationship between feminism, racialization and politics, and, of course, conceptions of feminism were also discussed (San Martin 1998). While creating spaces of feminist dialogue, Latin American women activists also maintained ties with transnational partisan groups, as well as developing independent global contacts. Central American refugee women created offshoots of home-country women's movements, and some transnational organizations formed women's committees. In the 1990s, Toronto Latin American feminists began to participate in regional and international women's encounters. This transnational thread of feminist politics now focused on building women-centred grassroots development partnerships with projects in Latin America (e.g. The 100 Mexican Women).

The early political critique of nationality-based partisan organizations developed by LAWC was channelled into the creation of Latin American women's advocacy organizations, including the Latin American Coalition to End Violence against Women and Children [LACEV 1992-2000] and Mujer (2002 to the present). A core group of women working in various service agencies and many of them active in the LAWC formed LACEV following a forum on Latin American women and violence organized in the late 1970s. LACEV became an institutionalized arena for advocacy and education on domestic violence for Latin American women and children. In contrast to the collective, LACEV's organizers decided not to adopt an explicitly feminist stance as a strategy to appeal to a broader spectrum of women. At the end of the 1990s, LACEV underwent a transition and re-emerged as Mujer.

The LACEV and later Mujer established an institutional basis from which Latin American women could connect with Canadian interlocutors in several arenas. Links with Canadian feminists were established around participation in International Women's Day celebrations and the National Action Committee on the Status of Women. Connections were also forged with those working on domestic violence and rape through the Wife Abuse Council, the Metropolitan Action Coalition against Violence and the Toronto Rape Crisis Centre. Contact with Canadian feminist organizations and specialized service 
agencies opened up networks and interlocution with Canadian actors and institutions - from state-related institutions such as the police to NGOs and community organizations involved in advocacy and service delivery. Volunteer work on domestic violence offered a way of connecting the personal and political, as well as opening up employment opportunities.

Women's advocacy organizations had important repercussions within and beyond the Latin American community. Women from the LAWC and LACEV were involved in a high-profile case involving the murder of a Latin American woman by her spouse (1992-3). They alleged that police mishandling of the case led to the woman's murder, and campaigned successfully to change police and forensic procedures surrounding spousal abuse (W1, various). A number of Latin American women received training and obtained employment in ethno-specific and other agencies as case workers and interpreters dealing with domestic violence. The campaign raised LACEV's profile among mainstream women's advocacy organizations and helped build momentum leading to a public inquiry, which laid the basis for the procedural changes.

A second space of feminist politics grew out of critiques of early Latin American feminist organizing for ignoring race and racism and for being hetero-normative. Women who identified as women of colour, or as indigenous, Afro-Latin American or of mixed ancestry led this critique, along with lesbians. The LAWC was criticized for being non-inclusive:

We made the connection between class and gender, but let's just say the Collective never got the issue of race. I don't mean to say we didn't recognize that there was racism, but I'm talking about inside the community ... not recognizing exclusion. Part of the Collective was white, but the dark ones were me and a Peruvian, there were no people of colour at that point, so the Collective never had an understanding of race. (CELAT 2)

Numerous organizational forms developed out of this critique. As a response to the perceived racism and elitism of the LAWC, Latin American women of colour created the collective Angry Women of Courage (1990s). The community radio programme Weaving Rebellions was established. Latin American lesbians later created the discussion and action group Don't Tell Me You Didn't Know.

A second thread in Latin American women's activism has centred on the development and delivery of ethno-specific social services for women and children. In the 1970s, women connected with LAWC participated in the creation of the Centre for Spanish Speaking People. Government funding allowed the CSSP to establish a broad-service 
women's programme. In the 1980s, Central American refugee women created projects focused on mutual aid, leadership training and education to address the overlapping realities of domestic and political violence (e.g. New Experiences for Refugee Women, Breaking the Silences). Funding cuts in the 1990s prompted the redefinition of such projects into non-ethno-specific women-focused agencies or nonethno-specific and non-gender-specific agencies. The 1990s also saw the expansion of Spanish-language services in existing non-ethnospecific women's organizations or programmes and the inclusion of Spanish-speaking female staff member in multi-service and/or multiethnic agencies.

Through their work in social services, Latin American feminist women generated a trenchant critique of male-dominated mainstream pan-ethnic organizations. Feminists pointed to a lack of diversity within agencies and the patriarchal complicity between the state and Latin American men.

There is a small bourgeoisie of people who provide services; in these organizations there are no women, no gays or lesbians, indigenous peoples ... The Canadian government is interested in dealing with people who see social services as a way to create clientelist relations. (CELAT 8)

Another feminist activist expanded on this pattern:

There was another Latin American centre ... the executive director was a very charismatic man who captured other men's attention. ... [T] he organization shot up in prestige. ... For years and years women had been doing the dirty work in community services ... and suddenly there is this group of guys whose hands are more or less clean and they are like the saviours of the community. (CELAT 13)

In the mid-1990s, the restructuring of the service sector complicated relations between Latin American feminists and mainstream panethnic organizations. The work of Latin American women's organizations was reduced, and the advocacy-centred organizations created by Latin American feminists became ineligible for sustained core funding. The Hispanic Development Council (HDC) began to compete directly with women's advocacy groups for funding. The relationship between the Centre for Spanish Speaking People (CSSP) and Latin American women's activist networks was also fractured. During this period, some feminist activists blamed larger organizations for 'eating up' smaller projects. Others saw the effort to mainstream women's social services as a necessary evil. Feminists lamented the general depoliticization of their work. 
I want to distinguish between two things: providing services and doing politics. I call it politics not because it's within a political party ... but offering services is worrying about numbers of clients. The funders impose criteria.... We have to send minutes for each meeting, monthly work updates, report for this and for that. It's like they are waiting ... seeing where you mess up so they can screw you. (Wom1, 1)

New bureaucratic requirements weakened the longstanding link between feminist advocacy (i.e. LACEV, Mujer) and responsive social service delivery for women and children.

The political trajectory of Latin American feminist women's activism in Toronto offers a second pattern of political socialization. Latin American refugee and immigrant women drew on their own experiences of domestic and political violence to articulate a feminist politics distinct from and critical of the ways of doing politics of country-of-origin partisan organizations. While moving away from transnational partisan projects, feminists took with them a social justice agenda. For two decades, they worked hard to maintain organizational links between feminist analysis and social service work. In the process, feminist activists generated a second moment of boundary work that questioned the patriarchal and exclusionary ways of doing politics of mainstream pan-ethnic organizations. Latin American women's bridging work has been multi-pronged and multi-scaled. Networks of interlocution connect them with other local, national and international women's organizations. It is the group's concern with social justice and equality for women and children, and not ethnicity per se, that generates mobilization.

\section{Discussion}

Our longitudinal analysis of Latin American community organizing in Toronto refines the institutional approach to immigrant politics. It captures formative moments, catalytic events and well-established as well as more incipient organizational forms; it also expands the scope of analysis to include immigrant politics in which ethnicity is not central to mobilization. The case study maps an immigrant pathway of political incorporation that is multi-layered, dynamic and has variable and coexisting modes and bases for organizing. For each migration wave, nationality is an important starting point for civic engagement, with variation across cohorts based on differences in pre-migration political socialization, contexts of exit and reception and the local and transnational political opportunity structures. Mainstream pan-ethnic organizing is a second organizational layer: organizations navigate 
between the administrative and funding imperatives of the state and in-group pressures for responsive and innovative social service delivery. Intersectional pan-ethnic organizations represent a third layer. Latin American women and artists constitute new political identities and organizational agendas in the interstices of country-of-origin and mainstream pan-ethnic organizations.

The concept of bridging and boundary and the specification of political cultures as civic toolkits refine our understanding of political socialization. Latin American women and artists engaged in internal critiques aimed at unsettling the primacy of national and mainstream pan-ethnic ways of doing politics. In the process of developing internal critiques and engaging in dialogues with new interlocutors, activists re-drew the boundaries of identity and community, identified new agendas and bridged activities to new allies and strategies. New or re-affirmed identities sometimes joined and certainly decentred national and regional identities and in the process refashioned the meanings of Latin American grassroots politics in the Canadian context. Through bridging and boundary work, community activists drew on available political culture repertoires, while at the same time learning new modes and bases for organizing.

Our findings specify that political opportunity structures can have direct and indirect effects on immigrant politics. For Latin Americans in Toronto contexts of exit and reception affected patterns of civic engagement in the early settlement period. Later, changes in state funding arrangements had a significant effect, as did changes in the design and delivery of settlement and social services. Regime change in home countries prompted a sharp decline in transnational partisan organizing, which in turn enabled Latin American artists to gain considerable autonomy, as demonstrated by their participation in the Living Maya Exhibit. Likewise, a strong state-funding environment facilitated the fairly autonomous growth of Latin American feminist women's work. However, cut-backs in the 1990s not only prompted a decline and de-politicization, it also forced feminist activists to renegotiate partnerships with mainstream pan-ethnic institutions. Changes in the POS shape the tenor of in-group negotiations and out-group dialogues and have complex and often indirect effects on differently organized groups.

Tracking organizations over time improves our ability to explain how immigrant political cultures and modes and bases of organizing are woven into the political landscape and transform the POS. Intersectional activists generated certain forms of institutional mainstreaming and made significant policy gains for Latin Americans and other racialized and otherwise marginalized population groups (e.g. Latin American artistic presence in alternative and mainstream 
galleries, ethno-specific service delivery, changes to police and forensic procedures on domestic violence). What is more, over time Latin American modes and bases of organizing entered the vocabulary of local politics. For example, transnational partisan politics incorporate Canadian solidarity workers. The Centre for Spanish Speaking Peoples' struggle to sustain a social action-oriented service delivery agenda set the tone for other pan-ethnic multi-service agencies, and pushed funders to recognize the diversity existent within pan-ethnic constituencies. Immigrant community activists thus bring their premigration and continually changing civic toolkits to bear on local politics.

The notion of boundary and bridging work allows us to overcome the assumption of the centrality of national identity as a platform and container for associational life and organizing. Instead of privileging national identity, we followed the boundary and bridging work, tracing institutional trajectories to uncover shifting patterns and redrawn boundaries of identity, agenda and politics. This allows us to foreground in-group and out-group horizontal and sectoral alliances, as well as responsiveness to state directives as part of the dialogues of political socialization that explain pathways of political incorporation. Longitudinal analysis strengthens a process-oriented understanding of immigrant political incorporation. Identifying the different layers of an immigrant pathway of political incorporation and charting the contested negotiations that can occur across these different modes and basis of organizing sheds light on the complex links and disconnects between civic engagement, grassroots organizing and electoral politics. It confirms that a narrow focus on immigrant citizenship acquisition and electoral participation offers a biased and incomplete interpretation of immigrant politics.

\section{Notes}

1. The mezzo-level refers to an intermediate set of formal and informal institutions and organizations that mediate between individuals and their primary institutions (family, friendship circles) and macro-structural systems.

2. This paper is based on research conducted as part of a SSHRC-funded comparative, collaborative project on the transnational and incorporationist practices of twelve ethnonational refugee groups in Canada. We are grateful to all the focus group participants who shared their experiences and political analysis with us. See http://www.yorku.ca/cohesion/ for a complete description of the project.

3. Abbreviations identify focus groups and numbers the respondent identifications used to maintain confidentiality: Arts =Artists groups; W1/W2 = Women's groups 1, 2; SOL1/ SOL2 $=$ Solidarity groups 1,2 . The CELAT interviews were conducted by the second author under the Civic Engagement of Latin Americans project in 2003.

4. Alucine, Toronto Latin Media Festival: http://www.alucinefestival.com/index.php 


\section{References}

BANNERJI, HIMANI 2000 'The paradox of diversity: the construction of a multicultural Canada and "women of color", Women's Studies International Forum, vol. 23, no. 5, pp. 537-60

BLOEMRAAD, IRENE 2006 'Becoming a citizen in the United States and Canada: structured mobilization and immigrant political mobilization', Social Forces, vol. 85, no. 2, pp. 667-95

BRETON, RAYMOND 1984 'The production and allocation of symbolic resources: an analysis of the linguistic and ethnocultural fields in Canada', The Canadian Review of Sociology and Anthropology, vol. 21, no. 2, pp. 123-44

BRETTELL, CAROLINE B. 2005 'Voluntary organizations, social capital, and the social incorporation of Asian Indian immigrants in the Dallas-Fort Worth metroplex', Anthropological Quarterly, vol. 78, no. 4, pp. 853-83

CORDERO-GUZMAN, HECTOR 2005 'Community-based organizations and migration in New York City', Journal of Ethnic and Migration Studies, vol. 31, no. 5, pp. 889-909

ESCOBAR, CRISTINA 2004 'Dual citizenship and political participation: migrants in the interplay of United States and Colombian politics', Latino Studies, vol. 2, no. 2, pp. 45-69 ESPIRITU, YEN LE 1992 Asian American Panethnicity: Bridging Institutions and Identities, Philadelphia, PA: Temple University Press

GARCIA BEDOLLA, LISA 2005 Fluid Borders: Latino Power, Identity, and Politics in Los Angeles, Los Angeles, CA: University of California Press

GERSTLE, GARY and MOLLENKOPF, JOHN (eds) 2001 E Pluribus Unum? Contemporary and Historical Perspectives on Immigrant Political Incorporation, New York: Russell Sage Foundation.

GLICK-SCHILLER, NINA, CAĞLAR, AYȘE and GULDBRANDSEND, THADDEUS 2006 'Beyond the ethnic lens: locality, globality and born-again incorporation', American Ethnologist, vol. 33, no. 4, pp. 612-33

GOLDRING, LUIN 2006 'Latin American transnationalism in Canada: does it exist, what forms does it take and where is it going?' in Victor Satzewich and Lloyd Wong (eds), Transnational Identities and Practices in Canada, Vancouver: University of British Columbia Press, pp. 180-201

HARDY-FANTA, CAROL 1993 Latina Politics, Latino Politics: Gender, Culture, and Political Participation in Boston, Philadelphia, PA: Temple University Press

JONES-CORREA, MICHAEL (ed.) 2001 Governing American Cities: Interethnic Coalitions, Competition, and Conflict, New York: Russell Sage Foundation.

2002 'On immigrant political incorporation', Workshop on Immigrant Political Incorporation, Syracuse University, NY.

LANDOLT, PATRICIA and GOLDRING, LUIN 2006 'Activist dialogues and the production of refugee political transnationalism: Chileans, Colombians and non-migrant civil society in Canada', paper given at the 2nd Conference of the International Network on Migration and Development, Cocoyoc, Mexico.

LEVITT, PEGGY 2005 'Building bridges: what migration scholarship and cultural sociology have to say to each other', Poetics, vol. 33, no. 1, pp. 49-62

MAGNUSSON, WARREN 1990 'The reification of political community', in R. B. J. Walker and Saul H. Mendlovitz (eds), Contending Sovereignties: Redefining Political Community, Boulder, CO: Lynne Rienner, pp. 45-60

MATA, FERNANDO 1985 'Latin American immigration to Canada: some reflections on the immigration statistics', Canadian Journal of Latin American and Caribbean Studies, vol. 10, no. 20 , pp. $35-40$

MORAWSKA, EWA 2001 'Immigrants, transnationalism, and ethnicization: a comparison of this great wave and the last', in Gerstle Gary and Mollenkopf John (eds), E Pluribus Unum? Contemporary and Historical Perspectives on Immigrant Political Incorporation, New York: Russell Sage Foundation, pp. 175-212 
MOYA, JOSE C. 2005 'Immigrants and associations: a global and historical perspective', Journal of Ethnic and Migration Studies, vol. 31, no. 5, pp. 833-64

NOLIN, CATHERINE 2006 Transnational Ruptures: Gender and Forced Migration, Aldershot, Hants, and Burlington, VT: Ashgate

ODMALM, PONTUS 2005 Migration Policies and Political Participation: Inclusion or Intrusion in Western Europe?, New York: Palgrave Macmillan

PERO, DAVIDE 2007 'Anthropological Perspectives on Migrants' Political Engagements' Working Paper No. 50, Centre on Migration, Policy and Society (COMPAS), Oxford, p. 35 PORTES, ALEJANDRO, ESCOBAR, CRISTINA and RADFORD, ALEXANDRIA WALTON 2007 'Immigrant transnational organizations and development: a comparative study', International Migration Review, vol. 41, no. 1, pp. 242-81

RIAÑO-ALCALÁ, PILAR and GOLDRING, LUIN 2006 'A Colombian diaspora? Characteristics, tensions and challenges in transnational engagements', paper given at the Capacity Building for Peace and Development: Roles of Diaspora Forum, University for Peace, Toronto, 19-20 October

RICHMOND, TED and SHIELDS, JOHN 2005 'NGO-government relations and immigrant services: contradictions and challenges', Journal of International Migration and Integration, vol. 6, no. 3-4, pp. 513-26

ROGERS, REUEL R. 2006 Afro-Caribbean Immigrants and the Politics of Incorporation: Ethnicity, Exception or Exit, New York City: Cambridge University Press

ROMERO, JORGE 1985 'History of LEFA', Polyphony: Bulletin of the Multicultural History Society of Ontario, vol. 7, pp. 29-30

SAN MARTIN, MAGALY 1998 'Picking up the thread: an oral history of the Latin American Women's Collective in Toronto, 1983-1990', master's thesis, Ontario Institute for Studies in Education, University of Toronto

SIEMIATYCKI, MYER and ISIN, ENGIN 1997 'Immigration, diversity and urban citizenship in Toronto', Canadian Journal of Regional Science, vol. 20, no. 1-2, pp. 73-102 SWIDLER, ANN 1986 'Culture in action: symbols and strategies', American Sociological Review, vol. 51, no. 2, pp. 273-86

THEISS-MORSE, ELIZABETH and HIBBING, JOHN R. 2005 'Citizenship and civic engagement', Annual Review of Political Science, vol. 8, pp. 227-49

TRINH VÕ, LINDA 2001 'The politics of social services for model minorities' in Marta López-Garza and David R. Díaz (eds), Asian and Latino Immigrants in a Restructuring Economy: The Metamorphosis of Southern California, Stanford, CA: Stanford University Press, pp. 241-72

VERBA, SYDNEY, SCHOLZMAN, KAY LEHMAN and BRADY, HENRY E. 1995 Voice and Equality: Civic Voluntarism in American Politics, Boston, MA: Harvard University Press VERTOVEC, STEVEN 2007 'Super-diversity and its implications', Ethnic and Racial Studies, vol. 30, no. 6, pp. 1024-54

WONG, JANELLE 2006 Democracy's Promise: Immigrants \& American Civic Institutions, Ann Arbor, MI: University of Michigan Press

PATRICIA LANDOLT is Assistant Professor of Sociology and Research Associate of the Cities Centre, University of Toronto.

ADDRESS: Cities Centre, University of Toronto, 455 Spadina Ave., Suite 400, Toronto, Ontario, M5S 2G8. Canada.

Email: landolt@utsc.utoronto.ca 
22 Patricia Landolt and Luin Goldring

LUIN GOLDRING is Associate Professor of Sociology and Research Associate of the Centre for Research on Latin American and the Caribbean (CERLAC), York University.

ADDRESS: CERLAC 240B York Lanes, 4700 Keele Street, York University, Toronto, Ontario M3J 1P3. Canada.

Email: goldring@yorku.ca 